\title{
MODERATION OF INFORMATION ASYMMETRY, SELF ESTEEM TO THE EFFECT OF PARTICIPATORY BUDGETING ON BUDGETARY SLACK
}

\author{
Seri Suriani ${ }^{1}$, Syamsu Alam ${ }^{2}$, Mursalim Nohong ${ }^{3}$ \\ ${ }^{1}$ Bosowa University Makassar \\ seri_suriani@ymail.com \\ ${ }^{2}$ Faculty of Economics and Business Hasanuddin University \\ syamsu.alam60@yahoo.com \\ ${ }^{3}$ Faculty of Economics and Business Hasanuddin University \\ mursalimnohong@fe.unhas.ac.id
}

\begin{abstract}
Supposed the budgetary participation does not always have a linear effect on budgetary slack. This is because of the factors asymmetry of information and self-esteem. The research aimed to find out whether information asymmetry and self-esteem are able to moderate the effects of participatory budgeting on budgetary slack. The data were collected using questionnaire. A number of samples in this research were 100 echelon SKPD's Government of South Sulawesi selected by purposive sampling method. The analysis technique used moderation regression analysis. The result showed that participatory budgeting had a positive effect on budgetary slack. Self-esteem Variable weakened the effect of participatory budgeting on budgetary slack, while variable of information asymmetry strengthened the effect of participatory budgeting on budgetary slack.
\end{abstract}

Keywords: Budgetary Slack, Participatory Budgeting, Self Esteem, Information Asymmetry. 


\section{INTRODUCTION}

Since regional autonomy was established, Government of South Sulawesi Provincial is required to realize good governance. Local governments use performance-based budgeting system which is the process of efficient development and participatory and use performance as a benchmark in the achievement of local budgets. However, the assessment of the performance motivates agents to undertake budgetary slack for the sake of a better career in the future (Suartana, 2010). In addition, the budgetary slack is also common in the planning and preparation phase of the local budget, because it is dominated by the interests of the executive and legislative, and less reflective of the needs of society (Kartiwa, 2004). Budgetary slack will result in misallocation of resources and bias in the evaluation of the performance of agents on accountability unit (Suartana, 2010).

For the Government of South Sulawesi Province, based on budget data past five years, as a whole has not shown indications of an increase in performance and a significant performance improvement in its implementation as described in the table below:

Table 1

Budget and Realization of Regional Original Income and Expenditure of South Sulawesi Province Budget 2011-2015 (in millions of rupiah)

\begin{tabular}{|c|c|c|c|c|c|c|}
\hline Year & $\begin{array}{c}\text { Budget of } \\
\text { Regional } \\
\text { Original } \\
\text { Income } \\
\mathbf{( R p )}\end{array}$ & $\begin{array}{c}\text { Realization } \\
\text { of Regional } \\
\text { Income } \\
\mathbf{( R p )}\end{array}$ & $\begin{array}{c}\text { Percentage of } \\
\text { Achievement } \\
\mathbf{( \% )}\end{array}$ & $\begin{array}{c}\text { Budget of } \\
\text { Regional } \\
\text { Expenditure } \\
\mathbf{( R p )}\end{array}$ & $\begin{array}{c}\text { Realization } \\
\text { of Regional } \\
\text { Expenditure( } \\
\text { (Rp) }\end{array}$ & $\begin{array}{c}\text { Percentage of } \\
\text { Achievement } \\
\text { (\%) }\end{array}$ \\
\hline 2011 & $\begin{array}{c}3.106 .899,5 \\
64\end{array}$ & $\begin{array}{c}3.110 .566,8 \\
41\end{array}$ & 100,11 & $2.703 .727,48$ & $2.548 .690,79$ & 94,19 \\
\hline 2012 & $\begin{array}{c}4.665 .214,4 \\
39\end{array}$ & $\begin{array}{c}4.433 .963,0 \\
19\end{array}$ & 95,40 & $\begin{array}{c}3.569 .468,40 \\
7\end{array}$ & $\begin{array}{c}3.388 .137,98 \\
9\end{array}$ & 94,92 \\
\hline 2013 & $\begin{array}{c}4.996 .499,3 \\
27\end{array}$ & $\begin{array}{c}4.867 .592,6 \\
11\end{array}$ & 97,42 & $4.438 .230,50$ & $4.081 .099,92$ & 91,95 \\
\hline 2014 & $5.650 .575,5$ & $5.503 .161,4$ & 97,39 & $4.981 .103,82$ & $4.499 .032,19$ & 90,32 \\
& 61 & 06 & & 4 & 2 & \\
\hline 2015 & $6.445 .779,1$ & $6.105 .815,0$ & 94,72 & $5.350 .327,15$ & $4.973 .655,47$ & 92,95 \\
& 61 & 95 & & 3 & 6 & \\
\hline
\end{tabular}

Source: Regional Financial Management Board of South Sulawesi Province, 2017

Seen from Table 1.1, the amount of expenditure budgeted to finance the program or activity indicates that there is incompleteness between the budget plan established and the realization of activity budget. This can be seen from the difference between the budget and the realization of expenditures that tends to excess budget, it shows that in the preparation of Regional Expenditure and Income Budget (APBD) is not yet in accordance with the applicable regulations and it is indicated the existence of programs or activities that have not been fully implemented and tend to happen indication of budgetary slack. 
In addition to the above phenomenon, few previous researchers that have examined the effect of participatory budget in budgetary slack declared inconsistent results, among others Merchant (1981), Young (1985), Frederick J. DeMicco, Steven J, and Dempsy (19980, Little, et al., (2002) Vincent K, Chong, Kar Ming Chong (2002), Yuhertiana (2004), Hafsah (2005), Falikhatun (2007), Sudarba (2010), Andriyani and Hidayati (2010), Andry Arifin Rahman (2012), Nila Aprila and Selvi Hardiyani (2012), Widiyastuti (2014) Zahirul Haque and Peter Brosnan (2015), states that a high participatory budgeting led to budgetary slack. Unlike the case with Schift and Lewin (1970), Onsi (1973), Dunk (1993), Minan (2005), Adam S, Maiga and Fred A. Jacobs (2007), Supanto (2010), Martjin and Wiersma (2011), Lislie Kren and Adam S.Maiga (2015), Laura Francis-Gladney, Robert B. Welker and Nace Magner (2015) that the high participatory budgeting can decrease the occurrence of budgetary slack. Based on data from Regional Expenditure and Income Budget (APBD) of South Sulawesi Province and inconsistency of these results, the researcher is motivated to examine the effect of participatory budgeting to budgetary slack with information asymmetry and self-esteem as a moderating variable at Regional Device Work Unit (SKPD) South Sulawesi Province.

\section{REVIEW OF LITERATURE AND DEVELOPMENT OF HYPOTHESES}

\section{LITERATURE AND HYPOTHESES}

\section{A. Participatory Budget and Budgetary Slack}

Based on agency theory, the participatory budget is a process of cooperation between agent and principal in making decisions related to regional budgeting. The regional budget prepared by the executive as agent and authorized by the legislative as a principal. Meaning of participatory in local governance is the involvement of Regional Device Work Unit (SKPD) in budgeting. Head of SKPD has the opportunity to submit proposals related to the implementation of the Regional Device Work Plan (RKPD) as a reference in preparing the Budget Work Plan of Regional Device Work Unit (RKASKPD)

Budget Work Plan of Regional Device Work Unit (RKA-SKPD) is a participatory budget document in local government internally related to the determination of budget allocation and performance target in Plan of Regional Expenditure and Income Budget (RAPBD), which later became Regional Expenditure and Income Budget (APBD) (Abdullah, 2012). However, the budget system based performance could be supposed to raise budgetary slack. Budgetary slack is an act that lower its production capability because the agent through its participation in budgeting has an opportunity in determining its standard of work (Young, 1985). Based on the above description, it can be hypothesized:

H1: Participatory Budget affects the budgetary slack.

\section{B. Participatory Budget, Budgetary Slack, and Information Asymmetry}

Based on the assumption of agency theory, people will act opportunistically that is prioritizing personal interests rather than the interests of the organization. The Principal can not monitor agency activities every day. Instead, the agent knows the important information relating to its capacity in work, work environment, and organizational units. This has caused the information asymmetry between principal and agent who participate in local budgeting. This is supported by Young (1985), Utomo (2006), Djasuli and Fadilah (2011) that the interaction of participatory budgeting and information asymmetry have a positive impact and significant on budgetary slack. According to Anthony and Govindarajan (2001) in Falikhatun (2007), the executive as agent tends to perform budgetary slack to secure his position in the government. Meanwhile, legislative as the 
principals tend to make a false contract with the executive. However, Dunk (1993) states that if a positive communication between the agent and the principal takes place, then the budgetary slack will decrease. Based on these descriptions, it can be hypothesized:

$\mathrm{H} 2$ : Information asymmetry moderates the effect of participatory budgeting on budgetary slack.

\section{Participatory Budget, Budgetary Slack, and Self Esteem}

Kreitner \& Kinicki (2003) stated that someone with a high self-esteem tends to see himself or herself more than others. Therefore, self-esteem is able to weaken the influence of participatory budgeting on budgetary slack, because if someone feels or herself so important, valuable and influential then confidence arises that what he or she does, it will succeed and create optimal results. Conversely, low Self Esteem means an employee that feels the lack of confidence what he does, it will not succeed and create results that are not optimal and tend to do budgetary slack.

This is supported by Nouri and Parker (1996), Ikhsan and Ane (2007) stated that budgetary slack is able to moderate the influence of participatory budget on budgetary slack. Similarly, Desmiyati (2009) that participatory budgeting and self-esteem interaction have a negative effect and not significant on budgetary slack. However, Kreitner \& Kinicki (2003) stated that self-esteem can not moderate the influence of participatory budgeting on budgetary slack. Based on the above description, it can be hypothesized:

H3: Self Esteem moderates the effect of participatory budgeting on budgetary slack.

Based on the description above it can be presented the design of this research in Figure 1 below:

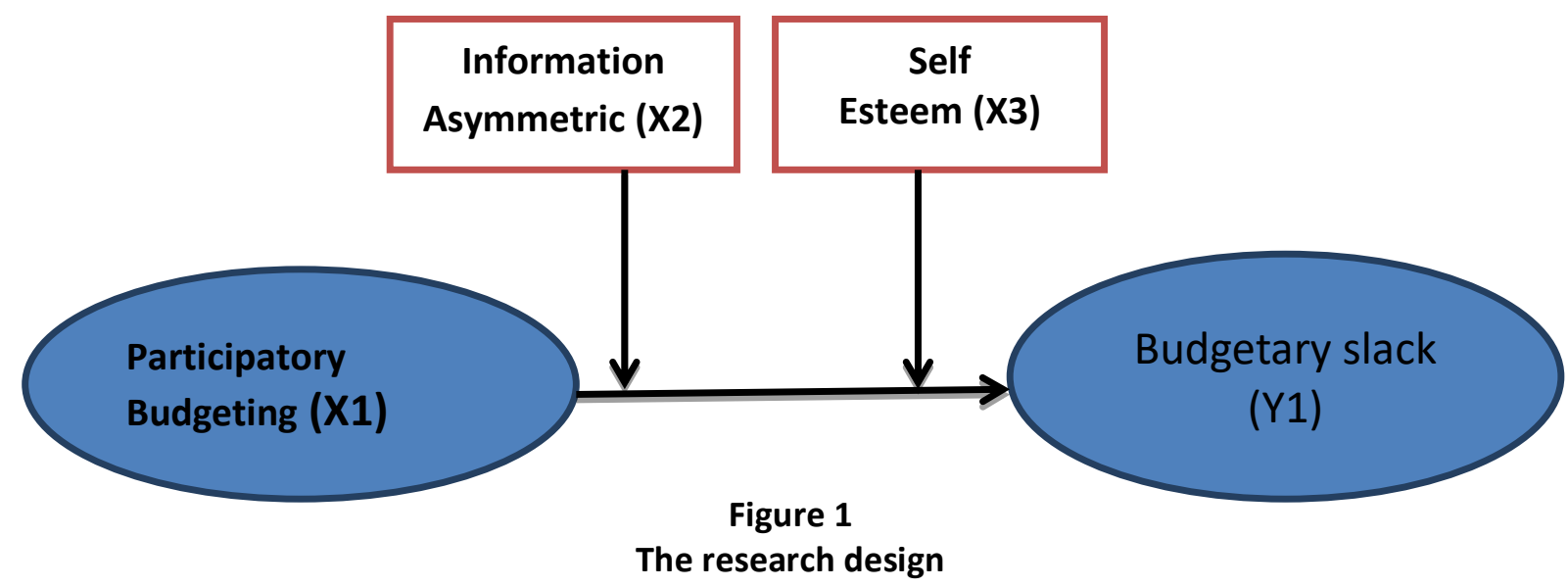

The research design in Figure 1 above describes the effect of the independent variable, that is participatory budgeting (X1) on the dependent variable namely budgetary slack (Y) with information asymmetry (X2), Self Esteem (X3) as moderating variable.

\section{RESEARCH METHOD}

The research was conducted in the Regional Work Units (SKPD) South Sulawesi Province. This research took place in May-July, 2017 because the local government delivered the Public Policy of Regional Expenditure and Income Budget (APBD) for the budget year 2017 by mid-June 2017. The population in this research is structural officials consisting of Echelon II, III, and IV who are still active on duty until July 2017 which amounted to 476 people. The sample in this research is structural officials who participate in regional budgeting. Sampling technique used purposive sampling. The sample criteria of this research are Echelon officials II / III / IV (Head of Division / Head of 
Department / Head of Office / Head of Sub-Section / Secretary of Regional Division) who participating directly in the budgeting process. This criterion is used to avoid the occurrence of sampling errors because not all echelon officials participate in budgeting.

Based on these criteria, It was obtained 105 respondents as a sample of research. Method of data collection used survey method in the form of questionnaires, namely a list of written statements relating to research variables. Because of this research used questionnaires then the instrument tests (validity test and reliability) were done. The answers of the respondents that have been collected (ordinal data) then tabulated and transformed into interval data. As a condition to fulfill the regression test, then the classical assumption test (test of normality and heteroscedasticity) were done first. Data analysis to test the hypothesis used MRA (Moderated Regression Analysis).

\section{RESULT OF RESEARCH AND DISCUSSION}

Questionnaires distributed in this research amounted to 105 questionnaires and returned as many as 105 questionnaires (Response Rate $=100 \%$ ). There were 5 questionnaires that were aborted because the filling was incomplete, so overall there were 100 questionnaires that were eligible for analysis (Usable Response Rate $=92.7 \%$ ).

The correlation coefficient value of all instruments above 0.30 means that the whole instrument is valid. The entire instrument has also been reliable with the Cronbach's alpha value of each participatory budgeting variable, information asymmetry, self-esteem, and budgetary slack, that is $0.744,0.892,0.655,0.871$. Normality test results indicate that this regression model has normal data distribution with Asymp value.Sig. (2-Tailed) of 0.423 . This model is also free from heteroscedasticity problems with significant values of participatory budgeting variable, budgetary slack, information asymmetry and self-esteem of $0.595,0.060,0.457,0.077,0.343$ and significance value of participatory budgeting interaction with information asymmetry and self-esteem respectively 0,089, 0,824.

Results of Moderated Regression Analysis (MRA) can be seen in Table 2.

Table 2

\section{Moderated Regression Analysis}

\begin{tabular}{|l|l|l|}
\hline Variable & $\begin{array}{l}\text { Unstandardized } \\
\text { Coefficients B }\end{array}$ & Sig. \\
\hline (Constant) & $-34,916$ & 0,002 \\
PA & 3,428 & 0,000 \\
AI & 1,025 & 0,001 \\
SE & 0,689 & 0,005 \\
PA*AI & $-0,065$ & 0,031 \\
PA*SE & $-0,059$ & \\
\hline Adjusted $\left(R^{2}\right)$ & 0,610 & \\
\hline Sing F & 0,00 & \\
\hline
\end{tabular}


In Table 2, the value of Adjusted $\mathrm{R}$ Square is 0.610 . This value means that 61 percent of the variation in budgetary slack change is explained by participatory budgeting variable, information asymmetry, self-esteem, the locus of control, and individual capacity. In Table 5, the significance value of $F$ is 0.000 less than 0.05 where this value means the model of this research has been a feasible test.

The result of the first hypothesis testing ( $\mathrm{H} 1)$ shows that participatory budgeting affects the budgetary slack. The regression coefficient of 3.428 indicates that participatory budgeting has a positive effect on budgetary slack. This suggests that the more individuals who participate in budgeting the higher the opportunity for budgetary slack.

Information asymmetry reinforces the effect of participatory budgeting on budgetary slack formulated in the second hypothesis $(\mathrm{H} 2)$. This happens because the value of beta has the opposite direction with the hypothesis that is the negative value of -0.065 . Based on this, the information asymmetry is unable to reinforce the effect of participatory budgeting on budgetary slack. This is caused by the possibility of information asymmetry in public sector organizations is very small because there are clear rules, duties, and authorities (Falikhatun, 2007).

The third hypothesis ( $\mathrm{H} 3)$, ie self-esteem is able to moderate the influence of participatory budgeting on budgetary slack. The regression coefficient of -0.059 indicates that the self-esteem variable weakens the effect of participatory budgeting on budgetary slack. If self-esteem is owned by individuals who participate in high budgeting, then the possibility of budgetary slack will decrease. Kreitner \& Kinicki (2003) stated that someone with a high self-esteem tends to see themselves more than others. Therefore, self-esteem is able to weaken the influence of participatory budgeting on budgetary slack, because if someone feels so important, valuable and influential then confidence arises that what he does, it will succeed and create optimal results.

\section{CONCLUSIONS AND SUGGESTIONS}

Based on the results of the previous analysis and discussion, it can be concluded that participatory budgeting has a positive effect on budgetary slack, as well as information asymmetry to strengthen the influence. This means that in order to reduce information asymmetry, the regional apparatus of South Sulawesi Province can apply information disclosure related to regional budgeting (APBD) in South Sulawesi Province. Local government can use the information media with the maximum and can be accounted for, even providing contact person from related officials. In contrast, Self Esteem weakens the influence of participatory budgeting on budgetary slack.

Suggestions for further research are able to use bureaucratic ethics, organizational culture, individual characteristics, the locus of control, motivation in moderating the influence of participatory budget on budgetary slack. 


\section{REFERENCES}

Abdullah, Syukriy. 2011. Penilaian Kinerja Keuangan. 29 November, 2011. Blog: www.wordpress.com

Abdullah, Syukriy. 2012. Anggaran Partisipatif di Pemerintahan Daerah: Samakah dengan Sektor Bisnis/Swasta?. 23 Februari, 2012. Blog: www.wordpress.com

Andriyani, Lilik., dan Hidayati, L.A. 2010. “Pengaruh Komitmen Organisasi terhadap Hubungan antara Kejelasan Sasaran Anggaran dan Partisipasi Anggaran dengan Senjangan Anggaran, Studi Kasus Pada Pemerintah Kabupaten Magelang. Universitas Muhammadiyah Magelang.

Belkoui, Ahmed. 1989. Behavioral Accounting. Connecticut: Quorum Books. Camman, C. 1976. "Effects of the Use of Control System". Accounting, Organizations, and Society. Vol. 4. Hal. 301-313.

Djasuli, Fadilah. 2011. "Pengaruh Asimetri Informasi dan Komitmen Organisasi terhadap Hubungan antara Partisipasi Anggaran dan Kesenjangan Anggaran" (tesis). Medan: Program Pascasarjana, Universitas Sumatera Utara.

Dunk, A.S., 1993, "The Efects of Budget Emphasis and Information Asymmetry on The Relation Between Budgetary Participation and Slack". The Accounting Review, Vol. 68 (2). Pp 400-410.

Dunk, A.S., dan H. Nouri. 1998. "Antecedents of Budgetary Slack: A Literature Review and Synthesis". Journal of Accounting Literature, Vol.17. Pp. 72- 96.

Dunk, Alan S. dan Hector Perera. 1996. "The Incidence of Budgetary Slack: A Field Study Exploration". Accounting, Auditing and Accountability Journal, No. 10 (5), 649-664.

Falikhatun. 2007. Interaksi Informasi Asimetri, Budaya Organisasi, dan Group Cohesiveness dalam Hubungan antara Partisipasi Penganggaran dan Budgetary Slack (Studi Kasus pada Rumah Sakit Umum Daerah Se Jawa Tengah). Simposium Nasional Akuntansi X. Unhas Makassar. 26-28 Juli 2007. ASPP-01.

Putu Novia Hapsari Ardianti,I Made Sadha Suardikha dan I.D.G.Dharma Suputra, Pengaruh Penganggaran. Falikhatun. 2007. "Interaksi Informasi Asimetri, Budaya Organisasi dan Group Cohesiveness dalam Hubungan Antara Partisipasi Penganggaran dan Budgetary Slack". Symposium Nasional Akuntansi X. Govindarajan, V. 1986. "Impact of Participation in the Budgetary Process on Managerial Attitudes and Performance: Universalistic and Contingency Perspective". Decision Science 17. Hal. 496-516.

Hansen, D.R., dan M.M. Mowen. 1997. Management Accounting, International Editions, McGrawHill. 
Hapsari, Yuliana, I. 2011. "Pengaruh Kapasitas Individu Terhadap Budgetary Slack dengan Self Esteem sebagai variabel Pemoderasi" (Disertasi). Yogyakarta

Ikhsan, Arfan, dan Ane, La. 2007. Pengaruh Partisipasi Anggaran terhadap Senjangan Anggaran dengan Menggunakan Lima Variabel Pemoderasi. Simposium Nasional Akuntansi X. Unhas Makassar. 26-28 Juli 2007. ASPP- 02.

Kartiwa, H.A. 2004. "Proses Penyusunan Anggaran (APBD) dan Arah Kebijakan Umum. Makalah. Sukabumi, 8 Desember 2004

Kreitner, Robert, dan Kinicki, Angelo. 2003. Perilaku Organisasi. Terjemahan: Erly Suandy, edisi pertama. Penerbit salemba empat: Jakarta.

Little, H.T., Magner, N.R., dan Welker, R.B. 2002. The Fairness of Formal Budgetary Procedures and Their Enactment: Relationships with Managers' Behavior. Group \& Organization Management 27. 2 (Jun 2002): 209-225.

Latuheru, Belianus Patria. 2005. "Pengaruh Partisipasi Anggaran terhadap Senjangan Anggaran dengan Komitmen Organisasi sebagai Variabel Moderating". Jurnal Akuntansi \& Keuangan. Vol 7. Hal. 117-130.

Lowe, E. A. dan R. W. Shaw. 1968. "An Analysis of Managerial Biasing: Evidence From a Company's Budgeting Proses". The Journal of Management Studies 5. Oktober. hal 304-315.

Lukka, K. 1988. "Budgetary Biasing in Organizations: Theoritical Framework and Empirical Evidence". Accounting, Organization, and Society 13. hal. 281- 301.

Mahsun, Mohamad., Sulistyowati, Firma., dan Purwanugraha, H.A. 2007. Akuntansi Sektor Publik. Edisi kedua. Yogyakarta. BPFE.

Mardiasmo. 2002. Akuntansi Sektor Publik. Penerbit Andi. Yogyakarta. Merchant, K.A. 1981. "The Design of Corporate Budgeting System: Influences on Managerial Behaviour and Performance". The Accounting Review, October: 813-829. Merchant, K. A. 1985. "Budgeting and Propersity to Create Budgetary Slack." Accounting, organization, and Society. 10. Hal. 201-210.

Mustikawati, Renny. 1999. "Pengaruh Locus of Control dan Budaya Paternalistik Terdadap Keefektifan Penganggaran Partisipasif dalam Peningkatan Kinerja Manajerial". Jurnal Bisnis Akuntansi, Vol.1 No.2 hal 96-119 ISSN : 2337-3067 E-Jurnal Ekonomi dan Bisnis Universitas Udayana 4.05 (2015) : 296-311 311

Nouri, H., dan R.J. Parker. 1996. "The Effect of Organizational Comitment on Relation Between Budgetary Participation and Budgetary Slack". Behavioral Research in Accounting, Vol 8. Pp. 74-89.

G Nugrahani, Tri Siwi., Sugiri, Slamet. 2004. "Pengaruh Reputasi Etika dan Self Esteem pada Budgeting Slack". Simposium Nasional Akuntansi VII Denpasar.

Onsi, M, 1973, "Factor Analysis of Behavioral Variables Affecting Budgetary Slack". The Accounting Review, Vol. 48. Pp. 535-548.

Prasojo, Eko., Kurniawan, Teguh., Hazan, Azwar. 2005. "Efisiensi Anggaran sebagai Faktor Kunci Keberhasilan dalam Pelaksanaan Program Inovasi di Kabupaten Jembrana. Administrasi Publik, Fakultas Ilmu Administrasi, Universitas Brawijaya, Vol. V, No. 2, Maret-Agustus 2005, hal 77-189 
Sandrya, Luh Putu. 2013. "Analisis Pengaruh Anggaran Partisipatif Pada Budgetary Slack Dengan Asimetri Informasi, Komitmen Organisasi, Budaya Organisasi, Dan Kapasitas Individu Sebagai Variabel Pemoderasi. (Studi kasus Pada Skpd Di Kabupaten Badung, Bali)". (Disertasi). Program pascasarjana Universitas Udayana.

Sinaga, M.T. 2013. "Pengaruh Partisipasi Anggaran Terhadap SenjanganAnggaran Dengan Locus Of Control Dan Organisasi Sebagai Variabel Pemoderasi". (Disertasi). Fakultas Ekonomi Universitas Negeri Padang.

Suartana, I.W. 2010. Akuntansi Keperilakuan (Teori dan Implementasi). Yogyakarta. ANDI. 19

Sudarba, I. K. 2010. “Pengaruh Partisipasi Penganggaran, Komitmen Organisasi dan Ketidakpastian Lingkungan pada Senjangan Anggaran (Studi Kasus Pada Satuan Kerja Perangkat Daerah Se-Kabupaten Tabanan)" (tesis). Denpasar: Universitas Udayana.

Sugiyono. 2011. Statistika Untuk Penelitian. Cetakan Ke-18. Bandung. ALFABETA.

Supanto. 2010. "Analisis Pengaruh Partisipasi Penganggaran terhadap Budgetary Slack dengan Informasi Asimetri, Motivasi, Budaya Organisasi sebagai Pemoderasi." (studi kasus pada politeknik negeri semarang)" (tesis). Semarang: Universitas Diponegoro.

Tsui, J.S.L. dan F.A. Gul. 1996. "Auditors' Behavior in an Audit Conflict Situation: A Research Note on the Role of Locus of Control and Ethical Reasoning". Accounting, Organizations and Society, Vol 21 No. 1

Yuhertiana, Indrawati. 2004. "Kapasitas Individu dalam Dimensi Budaya, Keberadaan Tekanan Sosial dan Keterkaitannya dengan Budgetary Slack". Wacana, Fakultas Ekonomi UPN "Veteran" Jawa Timur.

Young, S. M. 1985. Participative budgeting: The effects of risk aversion and asymmetric information on budgetary slack. Journal of Accounting Research (Autumn): 829-842. Available FromURL:http://www.jstor.org/discover/10.2307/2490840?uid=3738224\&uid=2\&ui $\mathrm{d}=4 \&$ sid $=47699042216 \mathrm{P} 907$ 